\title{
The redox chemistry of niobium(V) fluoro and oxofluoro complexes in LiF-NaF-KF
} melts

\author{
Matthiesen, Flemming; Christensen, Erik; Barner, Jens H. Von; Bjerrum, Niels
}

Published in:

Journal of The Electrochemical Society

Link to article, DOI:

$10.1149 / 1.1836906$

Publication date:

1996

Document Version

Publisher's PDF, also known as Version of record

Link back to DTU Orbit

Citation (APA):

Matthiesen, F., Christensen, E., Barner, J. H. V., \& Bjerrum, N. (1996). The redox chemistry of niobium(V) fluoro and oxofluoro complexes in LiF-NaF-KF melts. Journal of The Electrochemical Society, 143(6), 1793-1799. https://doi.org/10.1149/1.1836906

\section{General rights}

Copyright and moral rights for the publications made accessible in the public portal are retained by the authors and/or other copyright owners and it is a condition of accessing publications that users recognise and abide by the legal requirements associated with these rights.

- Users may download and print one copy of any publication from the public portal for the purpose of private study or research.

- You may not further distribute the material or use it for any profit-making activity or commercial gain

- You may freely distribute the URL identifying the publication in the public portal 
Editors, Chap. 6, ACS, Washington, DC (1989); and references therein.

3. B. W. Darvell and V. W-H. Leung, Chem. Br, 27, 29 (1991).

4. F. Franks, ibid., 27, 315 (1991).

5. R. Heyrovská, ibid., 27, 1114 (1991).

6. S. Arrhenius, Z. Phys. Chem., 1, 631 (1887).

7. W. R. Bousfield, Trans. Faraday Soc., 13, 141 (1917).

8. (a) R. Heyrovská, Coll. Czechosl. Chem. Commun., 53, 686 (1988); (b) ibid., 57, 2209 (1992); and (c) Unpublished results.

9. D. G. Archer, J. Phys. Chem. Ref. Data, 21, 793 (1992).

10. R. Heyrovská, (a) Abstracts, International Symposium on Molecular and Dynamic Approaches to Electrolyte Solutions, Tokyo, Japan, 1988; (b) Posters of XII International Symposium on Futures in Marine Chemistry, Brijuni, Croatia, 1993.

11. H. Ohtaki and N. Fukushima, J. Soln. Chem., 21, 23 (1992).

12. H. Ohtaki, Pure Appl. Chem., 65, 203 (1993).

13. R. Heyrovská, (a) Ábstract 662 , p. 999, The Electrochemical Society Extended Abstracts, Vol. 95-1, Reno, NV, May 21-26, 1995; (b) Abstract 425, p. 584, Abstract 426, p. 586, The Electrochemical Society Extended Abstracts, Vol. 84-1, Cincinnati, OH, May 6-11, 1984; (c) Abstract 652, p. 951, Abstract 653, p. 953, The Electrochemical Society Extended Abstracts, Vol. 842, New Orleans, LA, Oct. 7-12, 1984; (d) Abstract 442, p.660, Abstract 443 , p. 662 , Abstract 444 , p. 664 , The Electrochemical Society Extended Abstracts, Vol.
85-2, Las Vegas, NV, Oct. 13-18, 1985; (e) Abstract 463, p. 664, Abstract 472, p. 677, The Electrochemical Society Extended Abstracts, Vol. 87-1, Philadelphia, PA, May 10-15, 1987; (f) Abstract 1454, p. 1985, The Electrochemical Society Extended Abstracts, Vol. 872 , Honolulu, HI, Oct. 18-23, 1987.

14. W. J. Hamer and Y-C. Wu, J. Phys. Chem. Ref. Data, 1, 1067 (1972)

15. C. W. Davies, Ion Association, Butterworths, London (1962).

16. G. N. Lewis and M. Randall, J. Am. Chem. Soc., 43, 1112 (1921).

17. R. Bates, in Electrochemistry, Past and Present, ACS Symposium Series 390, J. T. Stock and M. V. Orna, Editors, Chap. 10, ACS, Washington, DC (1989).

18. K. S. Pitzer, J. C. Peiper, and R. H. Busey, J. Phys. Chem. Ref. Data, 13, 1 (1984).

19. A. Heydweiller, Z. Phys. Chem., 70, 128 (1910).

20. R. W. Gurney, Ionic Processes in Solution, Dover, New York (1953).

21. F. J. Millero, Chem. Rev., 71, 147 (1971).

22. B. E. Conway, Ionic Hydration in Chemistry and Biophysics, Elsevier, Amsterdam (1981).

23. H. S. Harned and B. B. Owens, The Physical Chemistry of Electrolytic Solutions, Reinhold, New York (1958).

24. R. Heyrovská, Chem. Phys. Lett., 163, 207 (1989).

25. International Critical Tables; Section III, McGrawHill, New York (1928).

\title{
The Redox Chemistry of Niobium(V) Fluoro and Oxofluoro Complexes in LiF-NaF-KF Melts
}

\author{
F. Matthiesen, E. Christensen, J. H. von Barner, and N. J. Bjerrum* \\ Materials Science Group, Department of Chemistry, Technical University of Denmark, DK-2800 Lyngby, Denmark
}

\section{ABSTRACT}

The electrochemical behavior of niobium(V) fluoro and oxofluoro complexes in eutectic LiF-NaF-KF (FLINAK) melts at $700^{\circ} \mathrm{C}$ has been studied by cyclic voltammetry. The fluoro complexes $\mathrm{NbF}_{7}^{2-}$, introduced into the melt by the addition of $\mathrm{K}_{2} \mathrm{NbF}_{7}$, can be reduced to niobium metal in two reversible steps involving one and four electrons, respectively. At $700^{\circ} \mathrm{C}$ the diffusion constants of the fluoro niobate complexes involved in these reduction steps, i.e., $\mathrm{NbF}_{7}^{2-}$ and $\mathrm{Nb}(\mathrm{IV}) \mathrm{F}_{x}^{(x-4)-}$, were determined to be $8.3 \times 10^{-6}$ and $3.4 \times 10^{-5} \mathrm{~cm}^{2} / \mathrm{s}$, respectively. Titration with equivalent amounts of oxide ions, introduced as $\mathrm{Na}_{2} \mathrm{O}$, leads to a conversion of $\mathrm{NbF}_{7}^{2-}$ to oxofluoro complexes of the type $\mathrm{NbOF}_{n}^{(n-3)-}$ and $\mathrm{NbO}_{2} \mathrm{~F}_{4}^{3-}$. At $700^{\circ} \mathrm{C}$ the conversion of $\mathrm{NbF}_{7}^{2-}$ to $\mathrm{NbOF}_{n}^{(n-3)-}$ is not complete, and the degree of conversion is shown to depend strongly on temperature. Thus, at $645^{\circ} \mathrm{C}$ the conversion is more nearly complete than at $700^{\circ} \mathrm{C}$, while the presence of NbOF ${ }_{n}^{(n-3)}-$ complexes cannot be identified in cyclic voltammograms obtained at $795^{\circ} \mathrm{C}$. It is concluded that the degree of conversion decreases with increasing temperature. At $\mathrm{Na}_{2} \mathrm{O} / \mathrm{K}_{2} \mathrm{NbF}_{7}$ molar ratios equal to three, electroactivity is still observed in the melt, indicating the presence of solute species. The products of reduction of the oxofluoro complexes have not been identified because the reduction of $\mathrm{NbOF}_{n}^{(n-3)-}$ ions cannot be obtained without simultaneous reduction of $\mathrm{Nb}(\mathrm{IV}) \mathrm{F}_{x}^{(x-4)-}$ ions, and at $\mathrm{Na}_{2} \mathrm{O} / \mathrm{K}_{2} \mathrm{NbF}_{7}$ molar ratios exceeding two, no deposits are obtained. The reduction of the oxofluoro complex $\mathrm{NbO}_{2} \mathrm{~F}_{4}^{3-}$, and complexes formed at $\mathrm{Na}_{2} \mathrm{O} / \mathrm{K}_{2} \mathrm{NbF}_{7}$ molar ratios exceeding two always proceed in one step.

\section{Introduction}

It has been known for some time that it is possible to plate with refractory metals, such as niobium and tantalum, by molten salt electrolysis. As solvents, both chloride and fluoride melts can be used. By using fluoride melts, plating with niobium is possible even when a certain amount of oxide is present in the molten salt bath. ${ }^{1}$

This is important from an industrial point of view, because the need for large amounts of expensive, very pure chemicals for the solvent melt can be avoided. Therefore, the electrochemistry of oxofluoro complexes of niobium is of considerable practical interest. Furthermore, this matter is also of interest in relation to investigations of the steps in the reduction of niobium fluoro complexes, as was discussed in a previous paper. ${ }^{1}$ Many discrepancies concerning the electrochemical reduction mechanism of

* Electrochemical Society Active Member.
$\mathrm{Nb}(\mathrm{V})$ fluoro species appear in the literature. ${ }^{1}$ In our previous publication it was demonstrated ${ }^{1}$ that it is likely that a number of the earlier investigations came to incorrect conclusions, because the melts used for the experiments were contaminated with oxygen from the atmosphere or from the chemicals used. The experimental difficulties in avoiding oxide in the melts are greatest when very low concentrations of $\mathrm{Nb}(\mathrm{V})$ are used. In the present work special care has been taken to keep the $\mathrm{O}: \mathrm{Nb}$ ratio sufficiently low, when there is no oxide added deliberately, and always to maintain a good control of this ratio.

We have recently investigated the influence of oxide on the electrochemical processes of tantalum in eutectic LiF$\mathrm{NaF}-\mathrm{KF}$ (FLINAK) melts. ${ }^{2}$ In this investigation, ${ }^{2}$ a simultaneous monitoring of the total oxide content in the melts was carried out by voltammetry using a glassy carbon working electrode. It was shown that the addition of oxide to a melt containing $\mathrm{TaF}_{7}^{2-}$ ions leads to the stepwise for- 
mation of $\mathrm{TaOF}_{5}^{2-}$ and $\mathrm{TaO}_{2} \mathrm{~F}_{x}^{(x-1)-}$ complexes. In addition to $\mathrm{TaF}_{7}^{2-}, \mathrm{TaOF}_{5}^{2-}$ was observed to reduce to tantalum metal in one multielectron reduction step.

Concerning niobium, several papers on the reduction mechanisms both in pure fluoride, ${ }^{1,3-7}$ and mixed chloridefluoride $^{8-12}$ melts have appeared in the literature. However, only a few of these $\mathrm{e}^{1,8,9,12,13}$ deal with the influence of adding oxide to the melts. From Raman spectroscopy, it is known that $\mathrm{Nb}(\mathrm{V})$ forms a number of oxofluoro complexes (e.g., $\mathrm{NbOF}_{5}^{2-}$ and $\mathrm{NbO}_{2} \mathrm{~F}_{4}^{3-}$ ) in FLINAK melts. ${ }^{14}$ In $\mathrm{NaCl}-\mathrm{KCl}$ melts with $\mathrm{K}_{2} \mathrm{NbF}_{7}$ and oxide added, the same complexes seem to be formed. ${ }^{15}$ In this case, it has been found ${ }^{15}$ that even a quite small oxide content in the melt disturbs the electrodeposition of niobium metal, causing formation of impure coatings containing niobates. In contrast to this, using FLINAK as a solvent melt, it seems to be possible to deposit pure niobium even with $\mathrm{O}: \mathrm{Nb}$ ratios up to one to one. ${ }^{1}$ Thus important differences between the two types of melts caused by solvent effects must exist. In our previous paper, ${ }^{1}$ preliminary results have already been given concerning the reduction of the above mentioned complexes in FLINAK melts. The present work comprises a more detailed study of the redox reactions taking place in FLINAK melts with $\mathrm{K}_{2} \mathrm{NbF}_{7}$ and with and without added oxide. We have extended the investigated $\mathrm{O} / \mathrm{Nb}$ range beyond three and have taken the influence of the temperature into consideration.

\section{Experimental}

Analytical grade alkali fluorides from Merck were purified separately in a platinum crucible by slow recrystallization from the molten state, as previously described. ${ }^{16}$ $\mathrm{K}_{2} \mathrm{NbF}_{7}$ was prepared as follows: hot solutions of $\mathrm{Nb}_{2} \mathrm{O}_{5}$ (from CERAC, "99.95\% purity") and KF (from Merck, analytical grade) in hydrofluoric acid were mixed. A white precipitate formed. The precipitate was collected by filtration and was then recrystallized in 40 weight percent (w/o) hydrofluoric acid. As an alternative, after mixing solutions containing the desired stoichiometric amounts of niobium and potassium, the liquid phase was removed by evaporation. Analysis by infrared spectroscopy as well as by potentiometric determination of the fluoride content showed no difference between the products prepared in the two different ways. $\mathrm{Na}_{2} \mathrm{O}$ was prepared by heating analytical grade $\mathrm{Na}_{2} \mathrm{O}_{2}$ from Merck in an alumina crucible under vacuum at $600^{\circ} \mathrm{C}$ for $12 \mathrm{~h}$. Analysis by titration with hydrochloric acid gave typically 98 w/o of the theoretical amount expected for $\mathrm{Na}_{2} \mathrm{O}$. After preparation and purification, the $\mathrm{Na}_{2} \mathrm{O}$ and the alkali fluorides were stored in glass ampuls sealed under vacuum. All handling and weighing was carried out in a glove box with an atmosphere of dry nitrogen (dew point approximately $-45^{\circ} \mathrm{C}$ ). The $\mathrm{K}_{2} \mathrm{NbF}_{7}$ salt was stored in closed polyethylene bottles in the same glove box.

All voltammetric experiments were carried out in a closed furnace under an argon $(99.99 \%)$ atmosphere. The furnace was equipped with a nickel tube with water cooled end covers. The upper end cover was a part of the cell, i.e., fixed to this cover were a holder for the crucible as well as three or four electrodes and a stainless steel tube for the addition of chemicals $\left(\mathrm{Na}_{2} \mathrm{O}\right.$ or $\left.\mathrm{K}_{2} \mathrm{NbF}_{7}\right)$. The cell was constructed of stainless steel and alumina ceramics for electrical insulation. The setup has been described previously in more detail.' Glassy carbon crucibles (V25, Carbone-Lorraine) served as containers for the melts. The typical amount of melt used in each experiment was $65 \mathrm{~g}$.

The heating procedure before each experiment was as follows: after introduction of the salts into the furnace, the furnace chamber was evacuated to a pressure of about $0.1 \mathrm{mbar}$ and heated to $400^{\circ} \mathrm{C}$ before a flow of argon gas was established. When the working temperature of $700^{\circ} \mathrm{C}$ was reached, the flow of argon gas was replaced by a small overpressure of argon gas $(20 \mathrm{kPa})$, which was then maintained during the rest of the experiment by an automatic pressure controlling system also described previously. ${ }^{2}$ In this work, it was observed that the lowest impurity level was reached when $\mathrm{K}_{2} \mathrm{NbF}_{7}$ was heated together with the alkali fluoride chemicals.

Before additions of $\mathrm{Na}_{2} \mathrm{O}$ were made, the chemicals were pressed into pellets inside the glove box. These pellets were then broken into smaller pieces of the desired weight. In order to avoid contamination of the furnace atmosphere during the addition, an argon gas flow was established so that argon gas flowed out of the furnace when the lid of the addition tube was opened.

A Schlumberger potentiostat, Solartron 1286, was used for the voltammetric measurements. Data were recorded on either a computer or an X-Y-recorder (Graphtec WX 3000 ). For high scan rates, a digital storage oscilloscope (Gould 1602) was used.

Electrode materials.-Glassy carbon working electrodes (for oxide determinations) were obtained from State Research Institute of Graphite, Moscow, $(1 \mathrm{~mm}$ in diam, Type SU-2500). A platinum wire (1 $\mathrm{mm}$ in diam) was used as a quasi-reference electrode. The counterelectrode was a $4 \mathrm{~cm}^{2}$ platinum foil. Working electrodes were made of platinum $(99.99 \%, 0.5 \mathrm{~mm}$ diam) or silver $(99.9 \%, 0.125 \mathrm{~mm}$ in diam) and were obtained from Goodfellow Cambridge, Limited. No differences between voltammograms obtained using platinum and silver working electrodes were observed. This was also the case for melts to which no sodium oxide had been added. We mention this because it has been reported recently ${ }^{17}$ that in chloride melts $(\mathrm{LiCl} / \mathrm{KCl}$ eutectic) the chloro complexes of $\mathrm{Nb}(\mathrm{V})$ and $\mathrm{Ta}(\mathrm{V})$ are reduced to $\mathrm{Nb}$ (IV) and $\mathrm{Ta}(\mathrm{IV})$, respectively, by silver.

We decided to use a simple platinum wire as quasi-reference electrode. In a previous investigation, ${ }^{1}$ a reference electrode based on the $\mathrm{Ni} / \mathrm{Ni}$ (II) redox couple was used. The reference melt in this electrode consisted of FLINAK saturated with $\mathrm{NiF}_{2}$ and was kept inside a porous boron nitride tube, which acted as a diaphragm. However, during the present work it was found that boron nitride reacts with $\mathrm{Nb}(\mathrm{V})$ in FLINAK. [The boron nitride was also found to react strongly with $\mathrm{Ta}(\mathrm{V})$ in FLINAK.] This was concluded from the fact that the shape of the voltammograms was changed after immersion of this electrode, compared with the voltammograms obtained with the platinum quasi-reference electrode. Thus, even though this electrode might give stable potentials, its presence changes the melt system, and therefore it was not used.

\section{Results and Discussion}

In Fig. 1 cyclic voltammograms of a FLINAK melt containing 1.00 mole percent $(\mathrm{m} / \mathrm{o}) \mathrm{K}_{2} \mathrm{NbF}_{7}$ and different concentrations of oxide are shown. The oxide concentrations given in the figure legend have not been corrected for the residual oxide content of the melt. When prepared as described in the Experimental section, the residual oxide content in a FLINAK melt containing $1.00 \mathrm{~m} / \mathrm{o} \mathrm{K}_{2} \mathrm{NbF}_{7}$ is $0.03 \mathrm{~m} / \mathrm{o}$. This value has been determined from the height of the anodic waves on the voltammograms obtained using glassy carbon working electrodes. This method of oxide determination has been described earlier. ${ }^{2,18,19}$ At each change of the oxide concentration by the addition of controlled amounts of $\mathrm{Na}_{2} \mathrm{O}$, the total oxide concentration of the melt is increased slightly more than the amount added because of experimental difficulties. Thus, the oxide/ $\mathrm{Nb}(\mathrm{V})$ molar ratios corresponding to the voltammograms shown in Fig. 1 actually vary from approximately $0(0.03)$ to approximately 1 .

In Fig. 1, curve A shows the voltammogram of a FLINAK melt with $1.00 \mathrm{~m} / \mathrm{o} \mathrm{K}_{2} \mathrm{NbF}_{7}$ added. Two reduction waves, $R_{1}$ and $R_{2}$, with peak potentials at -250 and $-975 \mathrm{mV}$, are observed. As is demonstrated later, $R_{1}$ is due to a one-electron process. Potentiostatic electrolysis at a cathodic potential corresponding to the reduction wave $R_{2}$ results in deposition of niobium metal on the cathode. By Raman spectroscopy it has been shown that $\mathrm{K}_{2} \mathrm{NbF}_{7}$ dissolves in FLINAK forming $\mathrm{NbF}_{7}^{2-}$ ions. ${ }^{14}$ The reduction of $\mathrm{NbF}_{7}^{2-}$ ions to niobium metal at $700^{\circ} \mathrm{C}$ thus proceeds in two steps involving one and four electrons, respectively. 


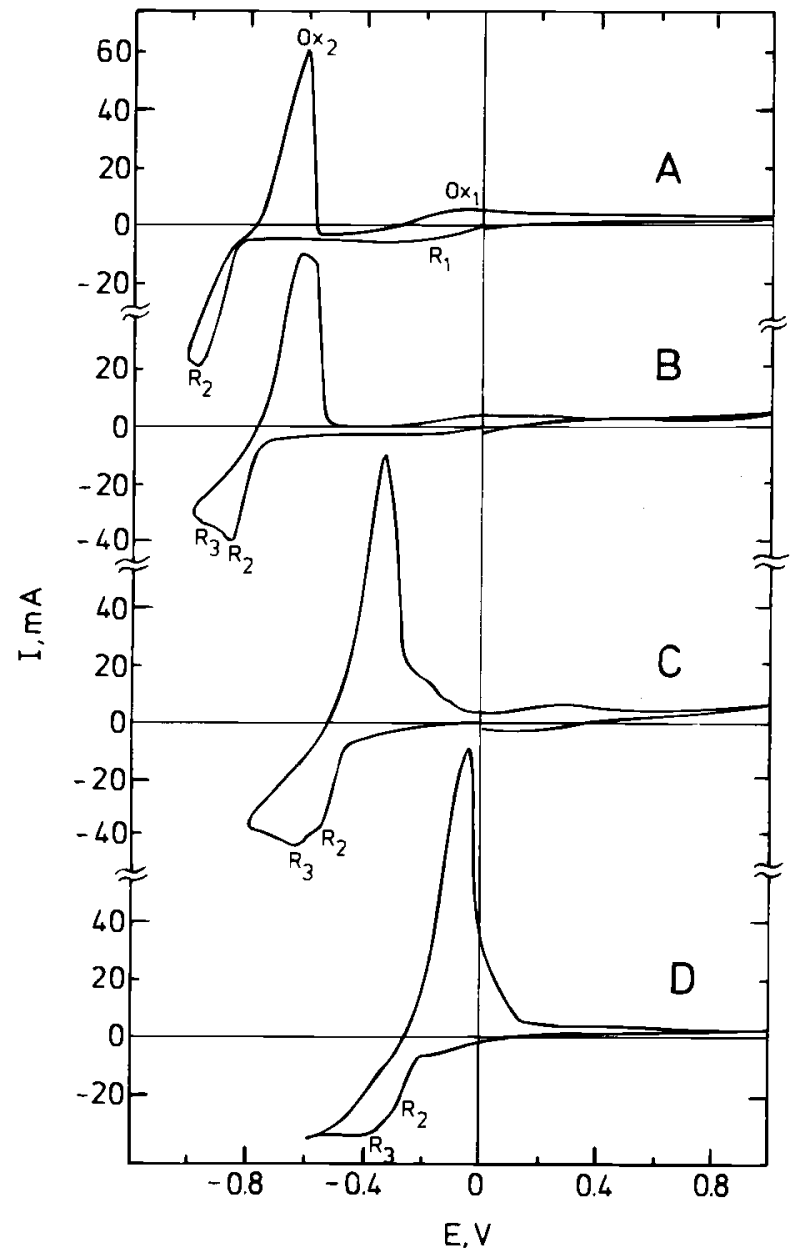

Fig. 1. Cyclic voltammograms of a FUNAK melt containing 1.00 $\mathrm{m} / \mathrm{o} \mathrm{K} \mathrm{NbF}_{7}$ and different concentrations of $\mathrm{Na}_{2} \mathrm{O}$. $\mathrm{Na}_{2} \mathrm{O}$ added: (A) 0 , (B) 0.30 , (C) 0.60 , and (D) $0.90 \mathrm{~m} / \mathrm{o}$. Platinum quasi-reference electrode and platinum working electrode. Surface area of the working electrode, $A=0.06 \mathrm{~cm}^{2}, t=700^{\circ} \mathrm{C}$, scan rate $=0.2 \mathrm{~V} / \mathrm{s}$.

When small amounts of sodium oxide are added to the melt, the positions of the reduction waves are shifted toward more positive potentials. This is due to instability of the platinum quasi-reference electrode under such conditions. From Fig. 1 it appears that this shift depends strongly on the oxide concentration. However, recognition of the reduction waves appearing in the voltammograms is still possible. Thus, the addition of sodium oxide until a $\mathrm{Na}_{2} \mathrm{O} / \mathrm{K}_{2} \mathrm{NbF}_{7}$ molar ratio of approximately 1 is reached results in a decrease of the peak currents of $R_{1}$ and $R_{2}$. The peak current of the reduction wave $R_{2}$ decreases linearly with increasing oxide concentration, but it does not approach zero when the $\mathrm{Na}_{2} \mathrm{O} / \mathrm{K}_{2} \mathrm{NbF}_{7}$ molar ratio approaches 1 . Simultaneously, a third reduction wave, $R_{3}$, appears at a potential that is $100 \mathrm{mV}$ more cathodic than the potential of $R_{2}$. This is seen on curves B-D in Fig. 1 where cyclic voltammograms of a FLINAK melt containing $1.00 \mathrm{~m} / \mathrm{o} \mathrm{K} \mathrm{NbF}_{7}$ and $0.30 \mathrm{~m} / \mathrm{o}$ (curve $\mathrm{B}$ ), $0.60 \mathrm{~m} / \mathrm{o}$ (curve $\mathrm{C}$ ), and $0.90 \mathrm{~m} / \mathrm{o}$ (curve $\mathrm{D}$ ) of $\mathrm{Na}_{2} \mathrm{O}$ are shown. Thus, in these voltammograms three reduction waves are observed.

The appearance of the reduction wave $R_{3}$ simultaneously with the decrease of the currents of $R_{1}$ and $R_{2}$ indicates that a ligand displacement reaction takes place so that new complexes are formed. This is consistent with Raman spectroscopic data which show that mono-oxofluoro complexes of the type $\mathrm{NbOF}_{n}^{(n-3)-}$, most likely $\mathrm{NbOF}_{5}^{2-}$, are present in FLINAK melts with similar oxide to niobium molar ratios. ${ }^{14}$ Apparently only one new reduction wave, $R_{3}$, appears and this would indicate that the reduction of the mono-oxofluoro niobate complexes proceeds in only one step. However, this conclusion may not necessarily be correct, because the exact shape of the $R_{3}$ wave cannot be obtained experimentally and is therefore unknown. The fact that the reduction waves due to the $\mathrm{NbF}_{7}^{2-}$ complex have not vanished at a $\mathrm{Na}_{2} \mathrm{O} / \mathrm{K}_{2} \mathrm{NbF}_{7}$ molar ratio equal to 1 indicates that the ligand displacement reaction

$$
\mathrm{NbF}_{7}^{2-}+\mathrm{O}^{2-} \rightarrow \mathrm{NbOF}_{n}^{(n-3)-}+(7-n) \mathrm{F}^{-}
$$

is not complete at $700^{\circ} \mathrm{C}$. Support for this assumption is obtained by the fact that electrolysis at a constant potential corresponding to the reduction wave $R_{2}$ in melts with the $\mathrm{Na}_{2} \mathrm{O} / \mathrm{K}_{2} \mathrm{NbF}_{7}$ molar ratio equal to 1 results in deposition of niobium metal at $700^{\circ} \mathrm{C}$ (identified by x-ray diffraction). This confirms that $R_{2}$ is indeed the metal forming reduction wave and not due to an intermediate step in the reduction of the oxofluoro complexes. Thus it seems likely that fluoro niobate ions are still present in the melt and that the metal deposition is due to the reduction of $\mathrm{Nb}$ (IV) fluoro complexes. Further aspects of the degree of ligand displacement and the reduction mechanism of niobium complexes appearing in FLINAK melts with the $\mathrm{Na}_{2} \mathrm{O} / \mathrm{K}_{2} \mathrm{NbF}_{7}$ molar ratio equal to 1 are discussed in more detail later.

It should be noted that when performing multiple potential sweep cycles on melts with $\mathrm{Na}_{2} \mathrm{O} / \mathrm{K}_{2} \mathrm{NbF}_{7}$ molar ratios in the vicinity of 1 , minor deviations between the voltammograms obtained in the first sweep and the subsequent ones are observed. Voltammograms obtained in the second and subsequent sweeps appear to be identical. Because of this behavior, which is presumably due to an electrode surface effect, we depict the voltammograms obtained during the second sweep (voltammogram $D$, Fig. 1) for this melt composition. The voltammograms A-C shown in Fig. 1 are recordings of the first sweeps.

As mentioned previously the process giving rise to $R_{1}$ in voltammogram A, Fig. 1, involves one electron. In Fig. 2 the variation of this reduction wave as a function of the scan rate is shown for scan rates ranging between $50 \mathrm{mV} / \mathrm{s}$ and $2 \mathrm{~V} / \mathrm{s}$. The $R_{1}$ peak potential $(-250 \mathrm{mV} v s$. the platinum reference electrode) as well as the peak potential of the corresponding anodic process $\mathrm{Ox}_{1}(-40 \mathrm{mV})$ appear to

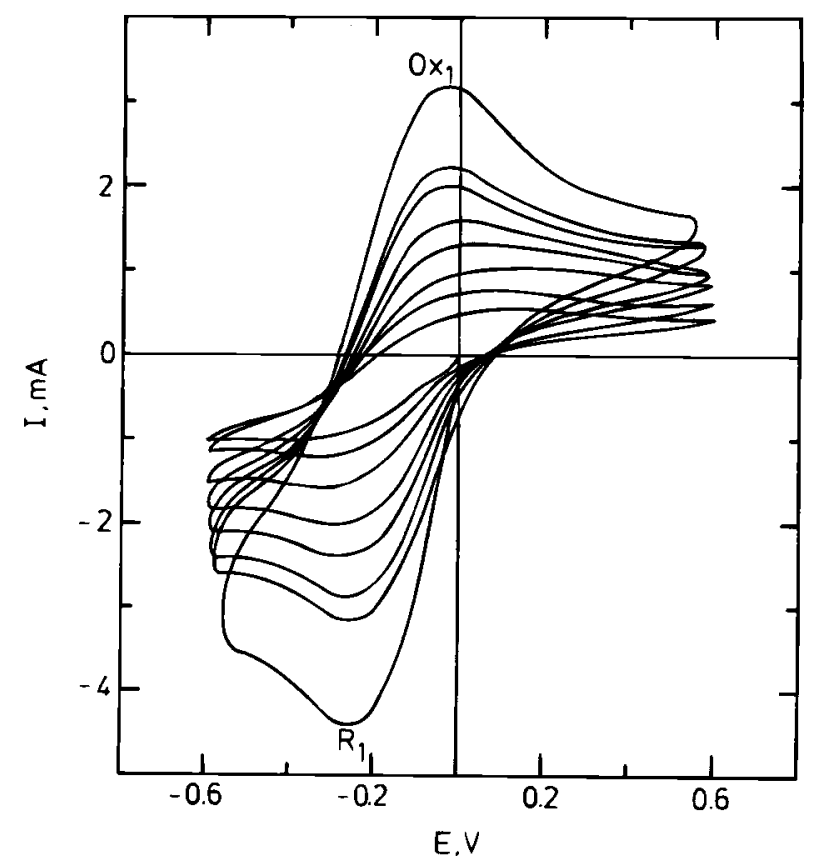

Fig. 2. Variation of the $\mathrm{Nb}(\mathrm{M})-\mathrm{Nb} / \mathrm{IV}$ reduction wave as a function of the scan rate, obtained in a FLINAK melt containing $0.50 \mathrm{~m} / \mathrm{o}$ $\mathrm{K}_{2} \mathrm{NbF}_{7}$. Platinum quasi-reference electrode, platinum working electrode, $A=0.03 \mathrm{~cm}^{2}, t=700^{\circ} \mathrm{C}$, scan rates shown: $0.05,0.1,0.2$, $0.4,0.6,0.8,1.0$, and $2.0 \mathrm{~V} / \mathrm{s}$. 
be independent of the scan rate. Furthermore the $R_{1}$ peak currents show a linear dependence on the square root of the scan rate. These features are characteristic of a reversible process. ${ }^{20}$ Thus the expression

$$
E_{\mathrm{C}}-E_{\mathrm{A}}=(R T \ln 10) / n F
$$

is valid. ${ }^{20} E_{\mathrm{C}}$ and $E_{\mathrm{A}}$ are the peak potentials of the cathodic and anodic waves ( $\mathrm{R}_{1}$ and $O \mathrm{Xx}_{1}$, respectively), and $n$ is the number of electrons involved. With the potential values of $\mathrm{R}_{1}$ and $\mathrm{Ox}_{1}$ given above one obtains a value of $n=1$.

Because both the reduced and the oxidized species participating in the process, $R_{1}$, are present in the liquid state, the following relationship between the peak current, $I_{\mathrm{p}}$, and the scan rate, $v$, is valid ${ }^{21}$

$$
I_{\mathrm{p}}=0.4463 n F A C_{\mathrm{ox}}\left(n F D_{\mathrm{ox}} v\right)^{1 / 2} /(R T)^{1 / 2}
$$

where $D_{\mathrm{ox}}$ is the diffusion coefficient, $C_{\mathrm{ox}}$ is the concentration of the oxidized species, and $A$ is the surface area of the working electrode. As expected a linear dependency between $I_{\mathrm{p}}$ and $v^{1 / 2}$ is observed and a value of the diffusion coefficient $D_{1}$ of $\mathrm{NbF}_{7}^{2-}=8.3 \times 10^{-6} \mathrm{~cm}^{2} / \mathrm{s}$ is obtained.

In Fig. 3, a linear $I_{\mathrm{p}}$ vs. $v^{1 / 2}$ dependency is observed for the reduction process $R_{2}$. For this reduction process, the reduction potential is observed to be independent of the scan rate. Thus, $R_{2}$ is also reversible. For a reversible process involving the deposition of an insoluble product the following $I_{\mathrm{p}}$ vs. $v^{1 / 2}$ relation is valid ${ }^{21}$

$$
I_{\mathrm{p}}=1.082 n F A C_{\mathrm{ox}}\left(n F D_{\mathrm{ox}} v\right)^{1 / 2} /(\pi R T)^{1 / 2}
$$

Thus, one obtains a value of $3.4 \times 10^{-5} \mathrm{~cm}^{2} / \mathrm{s}$ for the $\mathrm{Nb}$ (IV) fluoro complex. However, during the two-step reduction of the $\mathrm{Nb}(\mathrm{V})$ complexes, one might argue that the $\mathrm{Nb}(\mathrm{IV})$ concentration cannot be estimated with great certainty. During our calculation we have chosen a value equal to the bulk concentration of $\mathrm{Nb}(\mathrm{V}) \mathrm{F}_{?}^{2-}$.

In voltammogram A, Fig. 1, and in Fig. 2 a weak anodic current is observed at potentials more positive than $0 \mathrm{mV}$. Although only fluoro niobate $(\mathrm{V})$ complexes $\left(\mathrm{NbF}_{7}^{2-}\right)$ have been added to the melt, this anodic current indicates the presence of species with an oxidation step lower than +5 in the bulk melt, i.e., beyond the vicinity of the working electrode. It should be mentioned that voltammetric measurements performed on the pure solvent revealed no such anodic current. The reason for the reduction of fluoro niobate complexes in the fluoride melt is not clear. By observing the chlorine evolution, it can be shown ${ }^{22}$ that in chloride melts by using $\mathrm{NbCl}_{5}$ as the solute a redox reaction occurs between $\mathrm{Nb}(\mathrm{V})$ and chloride ions, resulting in the formation of $\mathrm{Nb}(\mathrm{IV})$. However, when using $\mathrm{NbF}_{7}^{2-}$ as the

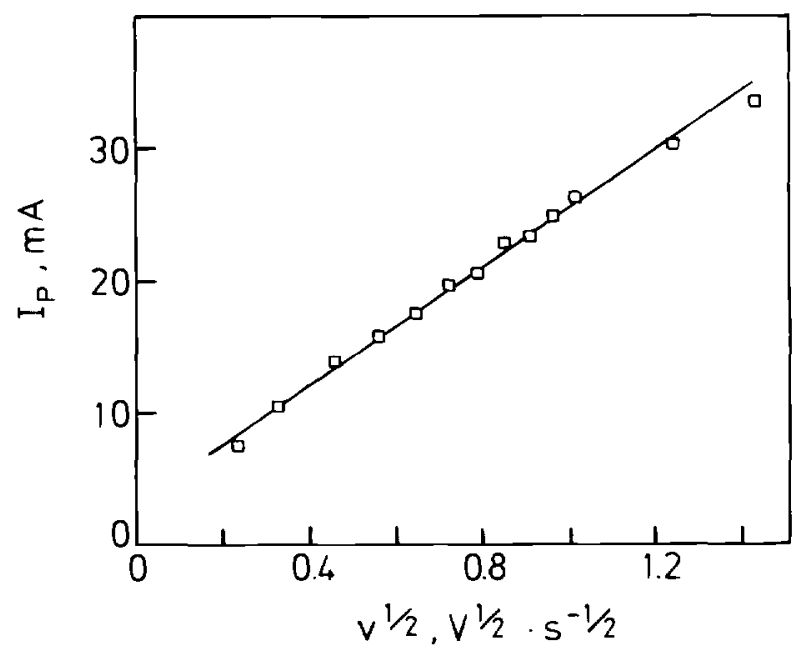

Fig. 3. The effect of scan rate effect on the peak current of the $\mathrm{Nb}(\mathrm{IV}) \mathrm{F}_{x}^{(x-4)-}$ reduction process. Platinum quasi-reference electrode, platinum working electrode, $A=0.03 \mathrm{~cm}^{2}, t=700^{\circ} \mathrm{C}, \mathrm{K}_{2} \mathrm{NbF}_{7}$ concentration $=0.50 \mathrm{~m} / \mathrm{o}$. solute in the same solvent a slight reduction of $\mathrm{Nb}(\mathrm{V})$ was also obtained, but in this case no chlorine evolution was observed. ${ }^{22}$

Figure 4 shows the cyclic voltammograms obtained from FLINAK melts with $\mathrm{Na}_{2} \mathrm{O} / \mathrm{K}_{2} \mathrm{NbF}_{7}$ molar ratios exceeding 1. The oxide/Nb(V) molar ratios corresponding to the voltammograms shown in Fig. 4 have been varied from approximately 1.3 to approximately 2 after correction for the residual oxide content.

With this increase of the oxide content, the peak currents of $R_{1}, R_{2}$, and $R_{3}$ decrease and a new reduction wave, $R_{4}$, appears. On voltammogram B, Fig. 4 , it can be observed that the potential of $R_{4}$ is approximately $100 \mathrm{mV}$ more cathodic than the potential of $R_{3}$. On voltammogram C, Fig. $4, R_{4}$ is the only wave observed. In spite of the broad character of this reduction wave, only one reduction process is proceeding. This can be seen by variation of the cathodic sweep limits. Because voltammogram C, Fig. 4, has been obtained for a melt with the oxide/ $\mathrm{Nb}(\mathrm{V})$ molar ratio approximately equal to 2 , it is likely only one $\mathrm{Nb}(\mathrm{V})$ complex is present, and that the $\mathrm{O}: \mathrm{Nb}$ ratio of this complex equals 2 . The presence of such $\mathrm{Nb}(\mathrm{V})$ complexes, probably $\mathrm{NbO}_{2} \mathrm{~F}_{4}^{3-}$, have been found in FLINAK melts with similar oxide to $\mathrm{Nb}(\mathrm{V})$ molar ratios by Raman spectroscopy. ${ }^{14}$

Potentiostatic electrolysis at a potential corresponding to $R_{4}$ gave no deposit. Some material was observed upon the cathode after cooling, and this material was soluble in water. Efforts made to identify the material by x-ray diffraction showed only lines that could be assigned to the residues of the solidified bulk melt.

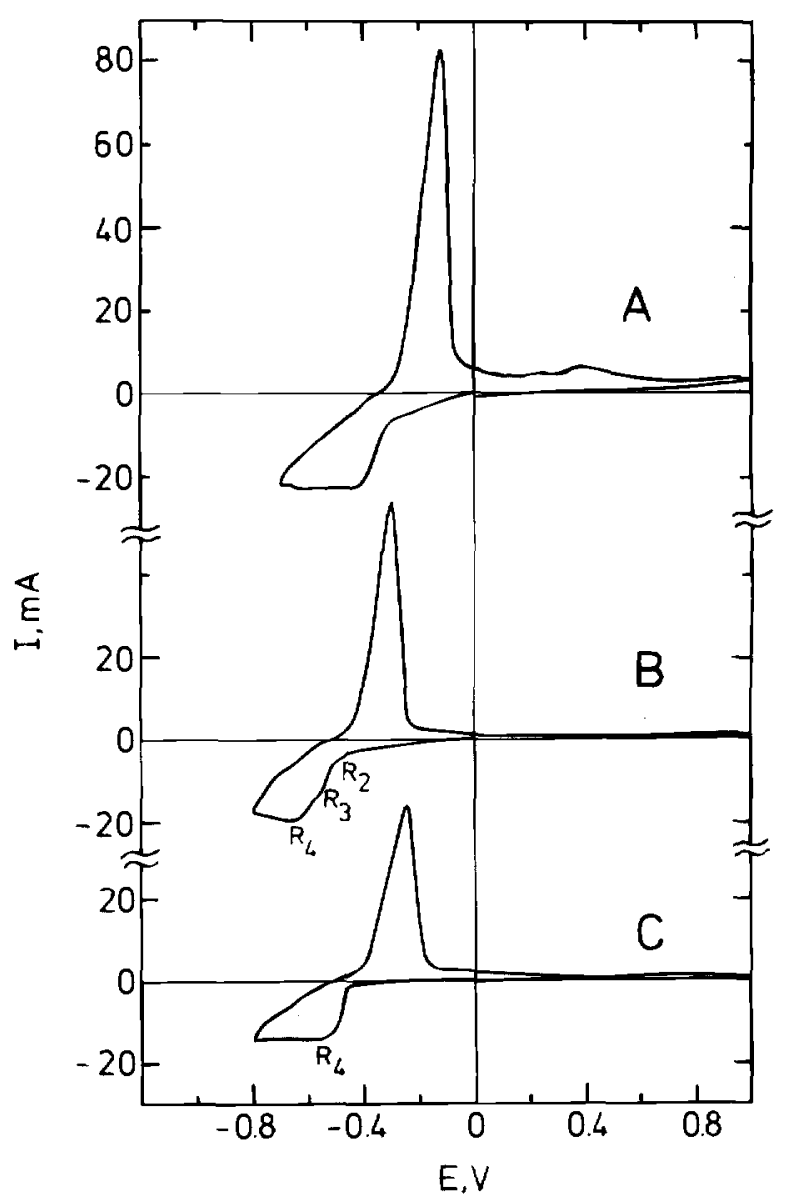

Fig. 4. Cyclic voltammograms of a FUNAK melt containing 1.00 $\mathrm{m} / \mathrm{O} \mathrm{K}_{2} \mathrm{NbF}_{7}$ and different oxide concentrations. $\mathrm{Na}_{2} \mathrm{O}$ concentrations: (A) 1.20 , (B) 1.50 , and (C) $1.80 \mathrm{~m} / \mathrm{o}$. Platinum quasi-reference electrode, platinum working electrode, $A=0.06 \mathrm{~cm}^{2}, t=700^{\circ} \mathrm{C}$, scan rate $=0.2 \mathrm{~V} / \mathrm{s}$. 
In Fig. 5 cyclic voltammograms of a FLINAK melt containing $1.00 \mathrm{~m} / \mathrm{o} \mathrm{K} \mathrm{K}_{2} \mathrm{NbF}_{7}$ and $2.5 \mathrm{~m} / \mathrm{o}$ (curve A) and $2.8 \mathrm{~m} / \mathrm{o}$ (curve $\mathrm{B}$ ) $\mathrm{Na}_{2} \mathrm{O}$ are shown. Taking into account the residual oxide content of the melt, the oxide to niobium molar ratio of the melt corresponding to curve $B$, Fig. 5 , is approximately equal to 3 . The voltammograms shown in Fig. 5 and 6 have been obtained using a silver working electrode.

In Fig. 5 it appears that increasing the oxide content until the oxide niobium molar ratios are approximately equal to 3 results in a decrease in $R_{4}$. Simultaneously, a new reduction wave, $R_{5}$, appears at a potential that is $400 \mathrm{mV}$ more negative than $R_{4}$. When even more $\mathrm{Na}_{2} \mathrm{O}$ is added, $\mathrm{R}_{4}$ disappears completely and only $R_{5}$ is left.

In Fig. 6 cyclic voltammograms of a FLINAK melt containing $1.00 \mathrm{~m} / \mathrm{o} \mathrm{K}_{2} \mathrm{NbF}_{7}$ and $2.5 \mathrm{~m} / \mathrm{o} \mathrm{Na} \mathrm{Na}_{2} \mathrm{O}$ at different cathodic sweep limits are shown. The oxidation peak, $\mathrm{Ox}_{5}$ can be seen to correspond to $R_{5}$. From Fig. 5 and 6 it appears that the current of $R_{5}$ is much larger than the current of the corresponding anodic peak, $\mathrm{Ox}_{5}$, Thus, the shape of the $\mathrm{R}_{5} / \mathrm{Ox}_{5}$ couple differs markedly from the shape of a wave typically associated with a metal deposition/dissolution process (e.g., as $\mathrm{R}_{2} / \mathrm{Ox}_{2}$ on voltammogram A, Fig. 1). Potentiostatic electrolysis at a cathodic potential corresponding to $R_{5}$ gave no electrode deposit. The fact that electroactivity is still present at an oxide to $\mathrm{Nb}(\mathrm{V})$ molar ratio exceeding 3 indicates that $\mathrm{Nb}(\mathrm{V})$ species are still present in the solution at these compositions. This observation is in agreement with Raman spectroscopic data. ${ }^{14}$

Temperature dependence of the ligand displacement reaction.-As mentioned previously, the reduction waves $R_{1}$ and $R_{2}$ due to the reduction of the $\mathrm{NbF}_{7}^{2-}$ complexes have not vanished at the $\mathrm{Na}_{2} \mathrm{O} / \mathrm{K}_{2} \mathrm{NbF}_{7}$ molar ratio approximately equal to 1 at $700^{\circ} \mathrm{C}$. Thus, the ligand displacement reaction resulting in the formation of the $\mathrm{NbOF}_{n}^{(n-3)-}$ complexes is not complete. Figure 7 shows cyclic voltammograms of a FLINAK melt with $1.00 \mathrm{~m} / \mathrm{o}$ $\mathrm{K}_{2} \mathrm{NbF}_{7}$ and $0.9 \mathrm{~m} / \mathrm{o} \mathrm{Na}_{2} \mathrm{O}$ added [i.e., an $\mathrm{O}: \mathrm{Nb}(\mathrm{V})$ molar ratio approximately equal to 1] at temperatures ranging between 645 and $795^{\circ} \mathrm{C}$. All the voltammograms shown are obtained during the second sweep. At $695^{\circ} \mathrm{C}$, both $\mathrm{R}_{2}$ and

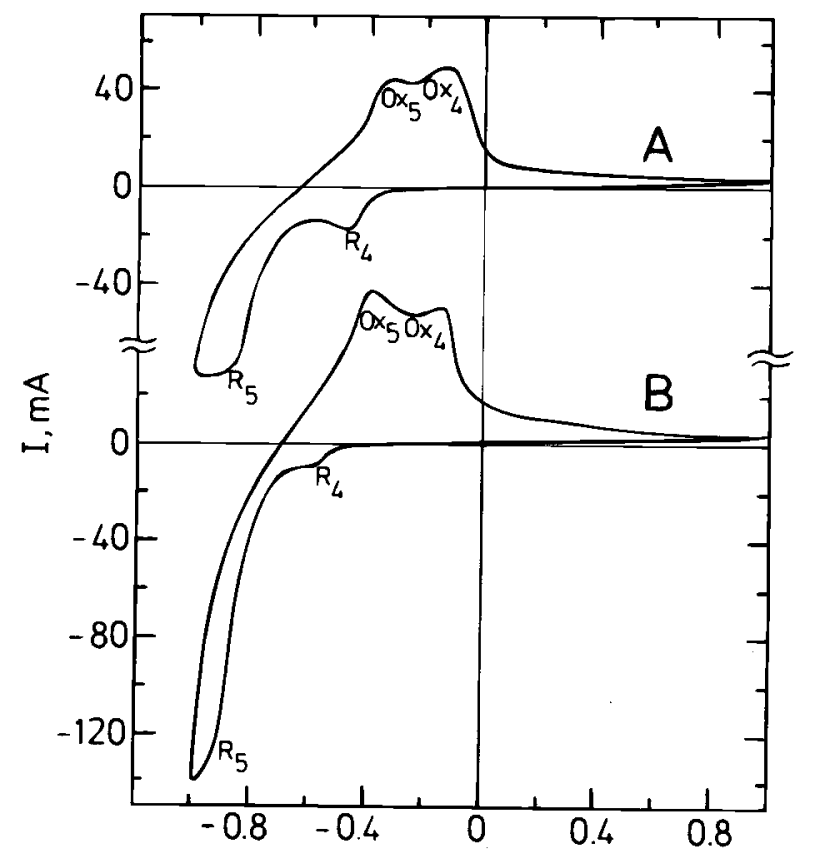

E.V

Fig. 5. Cyclic voltammograms of a FUNAK melt containing 1.00 $\mathrm{m} / \mathrm{o} \mathrm{K} \mathrm{NbF}_{7}$ and: (A) $2.50 \mathrm{~m} / \mathrm{o} \mathrm{Na} \mathrm{Na}_{2} \mathrm{O}$, (B) $2.80 \mathrm{~m} / \mathrm{o} \mathrm{Na} \mathrm{O}_{2} \mathrm{O}$. Platinum reference electrode, silver working electrode, $A=0.05 \mathrm{~cm}^{2}, t=$ $700^{\circ} \mathrm{C}$, scan rate $=0.2 \mathrm{~V} / \mathrm{s}$.

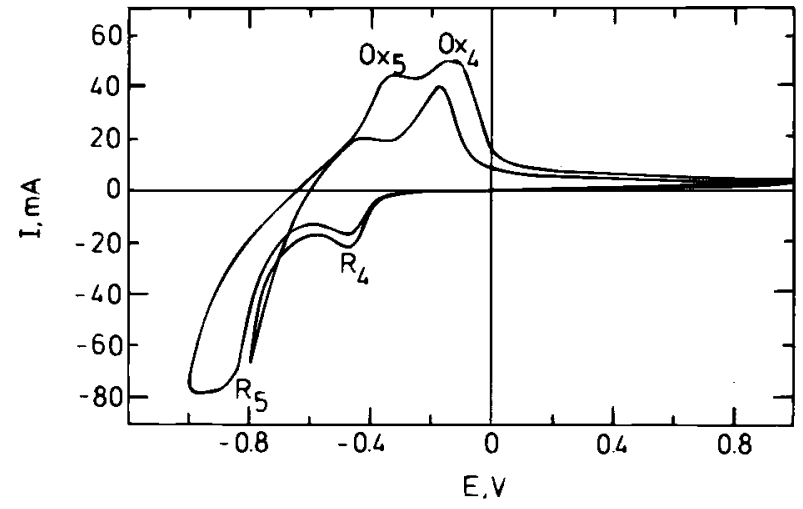

Fig. 6. Cyclic voltammogram of FLNAK melt containing $1.00 \mathrm{~m} / \mathrm{o}$ $\mathrm{K}_{2} \mathrm{NbF}_{7}$ and $2.50 \mathrm{~m} / \mathrm{o} \mathrm{Na}_{2} \mathrm{O}$. Platinum quasi-reference electrode, silver working electrode, $A=0.05 \mathrm{~cm}^{2}, t=700^{\circ} \mathrm{C}$, scan rate = $0.2 \mathrm{~V} / \mathrm{s}$. Cathodic sweep limits: -0.8 and $-1.0 \mathrm{~V}$, respectively.

$R_{3}$ are present, as in voltammogram D, Fig. 1. In Fig. 7 a change of $R_{2}$ and $R_{3}$ currents with temperature is observed. The ratio between the currents of the two waves is seen to vary markedly. Thus, at the highest temperature applied,

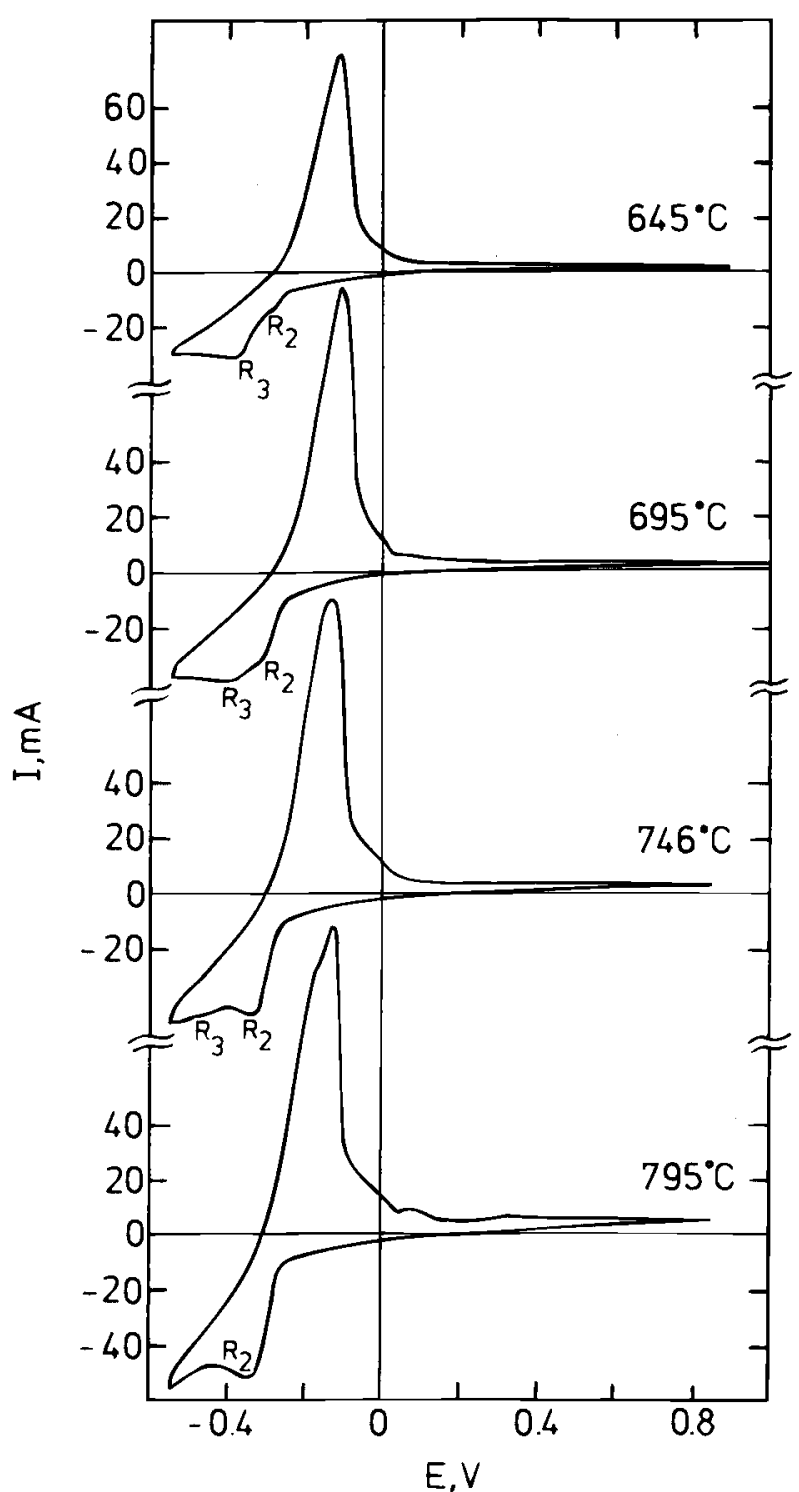

Fig. 7. Cyclic voltammograms of melts at various temperatures (in the temperature range 645 to $795^{\circ} \mathrm{C}$ ) containing $1.00 \mathrm{~m} / 0 \mathrm{~K}_{2} \mathrm{NbF}_{7}$ and $0.90 \mathrm{~m} / \mathrm{o} \mathrm{Na}_{2} \mathrm{O}$. Platinum quasi-reference electrode, platinum working electrode, $A=0.08 \mathrm{~cm}^{2}$, scan rate $=0.2 \mathrm{~V} / \mathrm{s}$. 
$795^{\circ} \mathrm{C}, \mathrm{R}_{2}$ is so dominating that $R_{3}$ cannot be identified. When the temperature is lowered, the ratio of the $R_{2}$ to $R_{3}$ currents diminishes, and the absolute current of $R_{2}$ decreases. Thus, a $746^{\circ} \mathrm{C} R_{3}$ can be identified whereas at $645^{\circ} \mathrm{C} R_{3}$ is dominating and $R_{2}$ has nearly disappeared. This temperature variation indicates a strong temperature dependence of the ligand displacement given by Eq. 1. The increase of the $R_{2}$ current when the temperature is raised indicates that the equilibrium is shifted to the left with increasing temperature. A similar behavior is observed by Raman spectroscopy in the same temperature range $(653$ to $790^{\circ} \mathrm{C}$ ) for melts with a similar $\mathrm{O}: \mathrm{Nb}(\mathrm{V})$ molar ratio (i.e., $0.93){ }^{14}$ At all of the temperatures examined, both species are seen by Raman spectroscopy. ${ }^{14}$ Thus, Eq. 1 is not complete, i.e, shifted to the right, in this temperature range. One might expect the reaction to become more complete at temperatures below $650^{\circ} \mathrm{C}$. However, at lower temperatures new features that impede the examination of the equilibrium are observed in the voltammograms. At present, efforts are being made in our laboratory to examine the nature of these low temperature features and to explain their appearance. It is important to note that the temperature variation depicted in Fig. 7 is observed regardless of the order in which the temperature has been varied. Thus, the apparent disappearance of the reduction wave due to the oxofluoro complex, $R_{3}$, at temperatures above $750^{\circ} \mathrm{C}$ is not due to a diminution of the oxide content of the melt, e.g., via reaction between oxide species and the carbon crucible.

Because $\mathrm{NbF}_{7}^{2-}$ species are still present in the melt at $\mathrm{O}: \mathrm{Nb}(\mathrm{V})$ molar ratio equal to 1 , it is interesting to speculate about what has happened to the oxide ions added that do not appear in the $\mathrm{NbOF}_{n}^{(n-3)-}$ complexes. One might suppose them to be present as free oxide ions. Unfortunately, at present no available methods allow experimental discrimination between eventually free oxide ions and oxide bonded in oxo complexes in fluoride melts. Instead of Eq. 1, a reaction between oxofluoro complexes and oxide ions forming either dioxofluoro complexes or, eventually, oxofluoro complexes with another $\mathrm{O}: \mathrm{Nb}(\mathrm{V})$ stoichiometry might proceed. In Fig. 8 cyclic voltammograms with different cathodic sweep limits of a FLINAK melt with the $\mathrm{O}: \mathrm{Nb}(\mathrm{V})$ molar ratio approximately equal to 1 , are shown. In this figure no trace of a reduction wave $100 \mathrm{mV}$ more cathodic than $R_{3}$ can be seen. Thus, there is no indication of the presence of species being reduced at the reduction

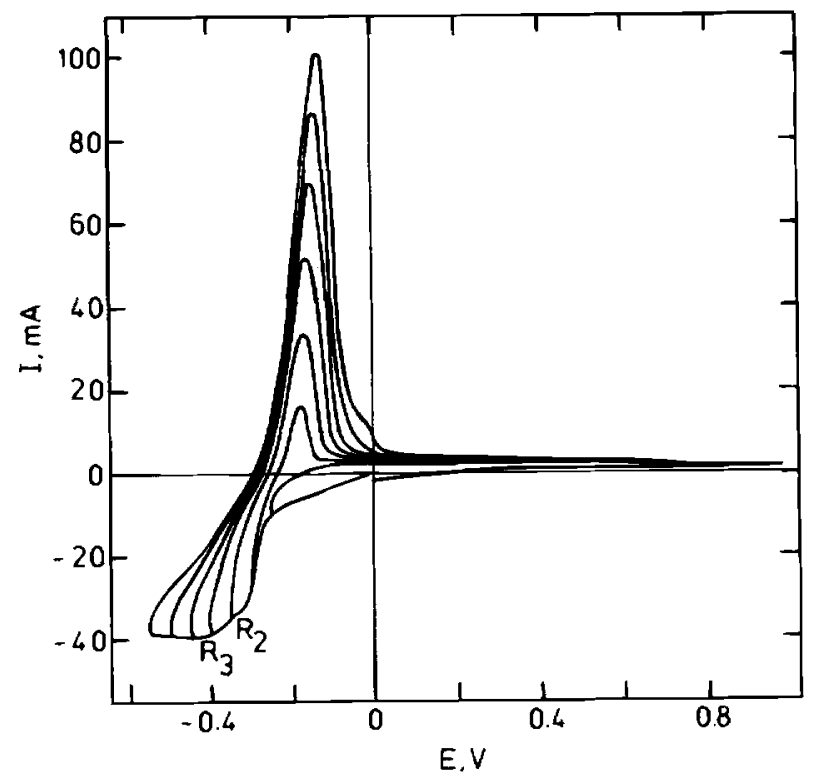

Fig. 8. Cyclic voltammograms of a FLNAK melt containing 1.00 $\mathrm{m} / \mathrm{o} \mathrm{K}_{2} \mathrm{NbF}_{7}$ and $0.90 \mathrm{~m} / \mathrm{o} \mathrm{Na} \mathrm{O}_{2} \mathrm{O}$, with different cathodic sweep $\mathrm{lim}$ its. Platinum working electrode, $A=0.08 \mathrm{~cm}^{2}$, platinum quasi-reference electrode, $t=700^{\circ} \mathrm{C}$, scan rate $=0.2 \mathrm{~V} / \mathrm{s}$. potential of $\mathrm{NbO}_{2} \mathrm{~F}_{4}^{3-}$. Similarly, in Raman spectra obtained for melts with a similar $\mathrm{O}: \mathrm{Nb}(\mathrm{V})$ molar ratio $(0.93)$ at $653^{\circ} \mathrm{C}$ no indication of the presence of dioxofluoro niobate complexes is observed. ${ }^{14}$ Thus, if a reaction between oxide ions and oxofluoro niobate complexes is proceeding, a remaining possibility is that the formed product precipitates. Verification of the presence of an eventual precipitate at $700^{\circ} \mathrm{C}$ or higher temperatures would require the possibility of quenching the melt. As seen from the temperature dependency of Eq. 1 the precipitate would dissolve when the temperature were lowered. Raman spectroscopic measurements performed in our laboratory on solidified melts with an $\mathrm{O}: \mathrm{Nb}(\mathrm{V})$ molar ratio equal to unity only showed the presence of monooxofluoro niobate complexes.

Another remaining question is: what is the reduction mechanism of the mono-oxofluoro niobate complex. It has been shown ${ }^{1}$ that $\mathrm{Nb}(\mathrm{V})$ is reduced quantitatively to $\mathrm{Nb}(\mathrm{IV})$ by niobium metal in FLINAK melts with the $\mathrm{Na}_{2} \mathrm{O}: \mathrm{K}_{2} \mathrm{NbF}_{7}$ molar ratio ranging between 0 and 1 . Thus, one might expect a reduction wave to appear in the voltammograms reflecting the $\mathrm{Nb}(\mathrm{V})$ - $\mathrm{Nb}(\mathrm{IV})$ reduction process of the $\mathrm{NbOF}_{n}^{(n-3)-}$ complexes when the $\mathrm{Na}_{2} \mathrm{O}: \mathrm{K}_{2} \mathrm{NbF}_{7}$ molar ratio approaches 1 . On the cathodic side of the voltammograms depicted in Fig. 7 a nonzero cathodic current is observed in the potential range between $0 \mathrm{mV}$ and the reduction wave $R_{2}$. This structure preceding the metal deposition wave does not contain a well-defined plateau. Therefore, the electrochemical methods applied in this work cannot be used for probing the number of electrons involved in the proceeding reaction. From Fig. 8 it can be seen that the reduction and oxidation structure obtained with a cathodic sweep limit corresponding to the prewave does not resemble that of a deposition process. Potentiostatic electrolysis in this potential region gave no deposit. Because $R_{2}$ is always present in voltammograms where $R_{3}$ is observed, even when the $\mathrm{Na}_{2} \mathrm{O}: \mathrm{K}_{2} \mathrm{NbF}_{7}$ molar ratios exceed 1 , it is not possible to determine the nature of the reduction product formed during the process corresponding to $R_{3}$.

Compared to results reported about the electrochemical reduction of niobate species with the $\mathrm{O}: \mathrm{Nb}(\mathrm{V})$ molar ratios equal to 1 in $\mathrm{KCl}-\mathrm{KF}-\mathrm{K}_{2} \mathrm{NbF}_{7}$ melts at $700^{\circ} \mathrm{C}{ }^{9}$ and in $\mathrm{NaCl}-\mathrm{KCl}-\mathrm{K}_{2} \mathrm{NbF}_{7}$ melts at $750^{\circ} \mathrm{C}{ }^{13}$ marked differences are observed. In both of these investigations a titration of the $\mathrm{NbF}_{7}^{2-}$ ions has been performed by the addition of $\mathrm{Nb}_{2} \mathrm{O}_{5}$. In both cases a quantitative conversion of $\mathrm{NbF}_{7}^{2-}$ to oxofluoro complexes is observed when the $\mathrm{Nb}_{2} \mathrm{O}_{5}: \mathrm{K}_{2} \mathrm{NbF}_{7}$ molar ratio equals $1: 3^{9,13}$ [i.e., an $\mathrm{O}: \mathrm{Nb}(\mathrm{V})$ molar ratio equal to 1]. The oxofluoro complexes formed are observed to reduce electrochemically in one step,,$^{9,13}$ and this reduction process is observed to take place at a potential that is less cathodic than the reduction of the $\mathrm{Nb}(\mathrm{IV})$ fluoro complexes formed during the two-step reduction of $\mathrm{NbF}_{7}^{2-},{ }^{9,13}$ Konstantinov et $a l .^{9}$ observed that the oxofluoro complex is reduced to niobium metal when the $\mathrm{Nb}_{2} \mathrm{O}_{5}: \mathrm{K}_{2} \mathrm{NbF}_{7}$ molar ratio equals 1:3. At higher $\mathrm{Nb}_{2} \mathrm{O}_{5}: \mathrm{K}_{2} \mathrm{NbF}_{7}$ (i.e., $\mathrm{O}: \mathrm{Nb}(\mathrm{V})$ ) molar ratios the authors suggest the formation of $\mathrm{NbO}_{2} \mathbf{F}_{4}^{3-}$. 9 Potentiostatic electrolysis of a $\mathrm{KCl}-\mathrm{KF}$ melt containing this complex results in the deposition of niobium oxides. ${ }^{9}$

In a recent investigation performed in $\mathrm{NaCl}-\mathrm{KCl}-\mathrm{NaF}$ $\mathrm{K}_{2} \mathrm{NbF}_{7}$ melts at $720^{\circ} \mathrm{C}$, Lantelme et al. ${ }^{12}$ also observed the formation of an oxofluoro complex after titration with $\mathrm{Na}_{2} \mathrm{O}$. This oxofluoro complex is seen to reduce in one step at a potential that is $100 \mathrm{mV}$ more cathodic than the reduction potential of the $\mathrm{Nb}(\mathrm{IV})$ fluoro complexes. ${ }^{12}$ According to the same work ${ }^{12}$ reduction of $\mathrm{Nb}$ (IV) fluoro complexes in melts where oxofluoro complexes are also present $[\mathrm{O}: \mathrm{Nb}(\mathrm{V})$ molar ratio $\geq 0.4]$ results in the deposition of niobium metal together with niobium suboxides (on nickel substrates). ${ }^{12}$ Thus, in those melts niobium suboxides can be deposited even without the reduction of the oxofluoro niobate complexes.

Summarizing this comparison between the present work and the references cited ${ }^{9,12,13}$ there seems to be a correlation between the influence of oxide upon the nature of the 
deposit that can be obtained and the amount of $\mathrm{F}^{-}$ions present in the melts. Thus, in $\mathrm{NaCl}-\mathrm{KCl}-\mathrm{NaF}-\mathrm{K}_{2} \mathrm{NbF}_{7}$ melts with a $\mathrm{F}^{-}: \mathrm{Nb}(\mathrm{V})$ molar ratio near 7 , oxide perturbs the niobium deposition at $\mathrm{O}: \mathrm{Nb}(\mathrm{V})$ molar ratios beyond $0.4{ }^{12}$ Using $\mathrm{KCl}-\mathrm{KF}$ as a solvent niobium metal can be obtained at $\mathrm{O}: \mathrm{Nb}(\mathrm{V})$ molar ratios equal to 1 whereas $\mathrm{NbO}$ can be obtained at higher $\mathrm{O}: \mathrm{Nb}(\mathrm{V})$ molar ratios. ${ }^{9}$ In a fluoride melt (FLINAK) niobium metal can be obtained at $\mathrm{O}: \mathrm{Nb}(\mathrm{V})$ molar ratios equal to 1 by reduction of $\mathrm{NbF}_{7}^{2-}$ that is still present at that composition.

A similar tendency seems to exist for tantalum. Thus, in $\mathrm{NaCl}-\mathrm{KCl}-\mathrm{K}_{2} \mathrm{TaF}_{7}$ melts with O:Ta(V) molar ratio equal to 1 , reduction of oxohalide complexes of $\mathrm{Ta}(\mathrm{V})$ results in the formation of metallic tantalum and tantalum-rich oxide compounds. ${ }^{23}$ In such melts, the $\mathrm{F}^{-}: \mathrm{Ta}(\mathrm{V})$ molar ratio is equal to 7 . In $\mathrm{KCl}-\mathrm{KF}-\mathrm{K}_{2} \mathrm{TaF}_{7}-\mathrm{Ta}_{2} \mathrm{O}_{5}$ melts with O:Ta(V) molar ratios equal to $1,{ }^{24}$ and in $\mathrm{LiF}-\mathrm{NaF}-\mathrm{KF}-\mathrm{K}_{2} \mathrm{TaF}_{7}-$ $\mathrm{Na}_{2} \mathrm{O}$ melts also with the $\mathrm{O}: \mathrm{Ta}(\mathrm{V})$ molar ratio equal to $1,{ }^{2}$ tantalum metal is deposited by the reduction of monooxofluoro tantalate complexes, i.e., $\mathrm{TaOF}_{6}^{2-}{ }^{23}$ and $\mathrm{TaOF}_{5}^{2-}{ }^{2}$ respectively. In both of the latter cases, the $\mathrm{F}^{-}$ion content did exceed a $\mathrm{F}^{-}$content corresponding to a $\mathrm{F}^{-}: \mathrm{Ta}(\mathrm{V})$ molar ratio of 7 .

\section{Conclusions}

In FLINAK melts at $700^{\circ} \mathrm{C}$, the reduction of $\mathrm{NbF}_{7}^{2-}$ ions to niobium metal proceeds in two steps

$$
\begin{gathered}
\mathrm{NbF}_{7}^{2-}+e^{-} \rightarrow \mathrm{NbF}_{x}^{(x-4)-} \\
\mathrm{NbF}_{x}^{(x-4)-}+4 e^{-} \rightarrow \mathrm{Nb}+(7-x) \mathrm{F}^{-}
\end{gathered}
$$

with both steps being reversible.

Adding oxide ions up to an $\mathrm{O}: \mathrm{Nb}(\mathrm{V})$ molar ratio of 1 results in the stepwise formation of mono-oxofluoro niobate complexes, $\mathrm{NbOF}_{5}^{2-}$. At $700^{\circ} \mathrm{C}$ the equilibrium

$$
\mathrm{NbF}_{7}^{2-}+\mathrm{O}^{2-} \rightleftarrows \mathrm{NbOF}_{5}^{2-}+2 \mathrm{~F}^{-}
$$

is not shifted completely to the right. Within the temperature range between 645 and $795^{\circ} \mathrm{C}$, it actually shifts to the left with increasing temperature. The mono-oxofluoro niobate complex reduces at potentials more cathodic than the reduction of $\mathrm{NbF}_{x}^{(x-4)-}$. The reduction product and the mechanism of the reduction cannot be identified from the present data, because the reduction wave is always overlapped by the wave of the $\mathrm{NbF}_{x}^{(x-4)-}$ reduction.

At $\mathrm{O}: \mathrm{Nb}(\mathrm{V})$ molar ratios exceeding 1 , the reduction of polyoxofluoro niobate(V) complexes proceeds at potentials even more cathodic than that for $\mathrm{NbOF}_{5}^{2-}$. Each complex reduces in one step, but the nature of the reduction products could not be established. Electroactivity due to polyoxo niobate species was still observed at an $\mathrm{O}: \mathrm{Nb}(\mathrm{V})$ molar ratio of 3 .

\section{Acknowledgments}

Financial support from the European Community (BRITE-EURAM Programme, No. BE-3359), the Danish
Academy of Technical Sciences, Danfoss A/S, is gratefully acknowledged.

Manuscript submitted Sept. 27, 1995; revised manuscript received March 15, 1996.

\section{REFERENCES}

1. E. Christensen, $\mathbf{X}$. Wang, J. H. von Barner, T Østvold, and N. J. Bjerrum, This Journal, 141, 1212 (1994).

2. L. Polyakova, E. Polyakov, F. Matthiesen, E. Christensen, and N. J. Bjerrum, ibid., 141, 2982 (1994).

3. I. Nakagawa and Y. Hirobayashi, Nippon Kagaku Kaishi, 1063 (1982)

4. S. Senderoff and G. Mellors, This Journal, 113, 66 (1966).

5. Z. Qiao and P. Taxil, J. Appl. Electrochem., 15, 259 (1985).

6. P. Los and J. Josiak, B. Electrochem., 5, 829 (1989).

7. T. Yoko and R. A. Bailey, in Proceedings of International Symposium on Molten Salt Chemistry and Technology, 1, 111 (1983).

8. M. Chemla and V. Grinevitch, Bull. Soc. Chim. (France), No. 3, 853 (1973).

9. V. I. Konstantinov, E. G. Polyakov, and P. T. Stangrit, Electrochim. Acta, 26, 445 (1981).

10. A. Barhoun, V. Berghoute, and F. Lantelme, J. Alloys Comp., 179, 241 (1992).

11. F. Lantelme and Y. Berghoute, This Journal, 141, 3306 (1994).

12. F. Lantelme, Y. Berghoute, J. H. von Barner, and G. S. Picard, ibid., 142, 4097 (1995).

13. S. A. Kuznetsov, A. L. Glagolevskaya, V. V. Grinevich, and P. T. Stangrit, Soviet Electrochemistry, 26, 1098 (1992).

14. J. H. von Barner, E. Christensen, N. J. Bjerrum, and B. Gilbert, Inorg. Chem., 30, 561 (1991).

15. J. H. von Barner, R. W. Berg, Y. Berghoute, and F. Lantelme, Molten Salt Forum., 1-2, 121 (1993).

16. N. J. Bjerrum, R. W. Berg, E. Christensen, D. H. Kerridge, and J. H. Von Barner, Anal. Chem., 67, 2129 (1995).

17. G. A. Voyiatzis, E. A. Pavlatou, G. N. Papatheodorou, M. Bachtler, and W. Freyland, in Molten Salt Chemistry and Technology 1993, M.-L. Saboungi and H. Kojima, Editors, PV 93-9, p. 252, The Electrochemical Society Proceedings Series, Pennington, NJ (1993).

18. A. J. Calandra, C. E. Castellano, and C. M. Ferro, Electrochim. Acta, 24, 425 (1979).

19. S. H. White, in Molten Salt Techniques, Vol. 1, D Lovering and R. Gale, Editors, p. 50, Plenum Press, New York (1983).

20. Southampton Electrochemistry Group, Instrumental Methods in Electrochemistry, Ellis Horwood Ltd., Chichester (1985).

21. Z. Galus, Fundamentals of Electrochemical Analysis, p. 115, Ellis Horwood Ltd., Chichester (1976)

22. L. Arurault, J. Bouteillon, and J. C. Poignet, This Journal, 142, 16 (1995)

23. F. Lantelme, A. Barhoun, G. Li, and J-P. Besse, ibid., 139, 1249 (1992).

24. V. I. Konstantinov, E. G. Polyakov, and P. T. Stangrit, Electrochim. Acta, 23, 713 (1978). 